\title{
TGF $\beta$ and EGF signaling orchestrates the AP-1- and p63 transcriptional regulation of breast cancer invasiveness
}

\author{
Anders Sundqvist $\mathbb{D}^{1} \cdot$ Eleftheria Vasilaki ${ }^{1}$ Oleksandr Voytyuk ${ }^{1} \cdot$ Yu Bai $^{1} \cdot$ Masato Morikawa $\mathbb{E}^{2}$. \\ Aristidis Moustakas $^{1} \cdot$ Kohei Miyazono ${ }^{1,2} \cdot$ Carl-Henrik Heldin $\mathbb{D}^{1} \cdot$ Peter ten Dijke ${ }^{1,3} \cdot$ Hans van Dam ${ }^{3}$
}

Received: 23 September 2019 / Revised: 4 April 2020 / Accepted: 9 April 2020 / Published online: 29 April 2020

(c) The Author(s) 2020. This article is published with open access

\begin{abstract}
Activator protein (AP)-1 transcription factors are essential elements of the pro-oncogenic functions of transforming growth factor- $\beta$ (TGF $\beta$ )-SMAD signaling. Here we show that in multiple HER2 + and/or EGFR + breast cancer cell lines these AP1-dependent tumorigenic properties of TGF $\beta$ critically rely on epidermal growth factor receptor (EGFR) activation and expression of the $\Delta \mathrm{N}$ isoform of transcriptional regulator p63. EGFR and $\triangle \mathrm{Np} 63$ enabled and/or potentiated the activation of a subset of TGF $\beta$-inducible invasion/migration-associated genes, e.g., ITGA2, $L A M B 3$, and $W N T 7 A / B$, and enhanced the recruitment of SMAD2/3 to these genes. The TGF $\beta$ - and EGF-induced binding of SMAD2/3 and JUNB to these gene loci was accompanied by p63-SMAD2/3 and p63-JUNB complex formation. p63 and EGFR were also found to strongly potentiate TGF $\beta$ induction of AP-1 proteins and, in particular, FOS family members. Ectopic overexpression of FOS could counteract the decrease in TGF $\beta$-induced gene activation after p63 depletion. p63 is also involved in the transcriptional regulation of heparin binding (HB)-EGF and EGFR genes, thereby establishing a self-amplification loop that facilitates and empowers the pro-invasive functions of TGF $\beta$. These cooperative pro-oncogenic functions of EGFR, AP-1, p63, and TGF $\beta$ were efficiently inhibited by clinically relevant chemical inhibitors. Our findings may, therefore, be of importance for therapy of patients with breast cancers with an activated EGFR-RAS-RAF pathway.
\end{abstract}

\section{Introduction}

Transforming growth factor- $\beta$ (TGF $\beta$ )-induced signaling has both positive and negative functions in cancer; in late

Supplementary information The online version of this article (https:// doi.org/10.1038/s41388-020-1299-z) contains supplementary material, which is available to authorized users.

Anders Sundqvist

anders.sundqvist@imbim.uu.se

$\triangle$ Hans van Dam

vdam@lumc.nl

1 Department of Medical Biochemistry and Microbiology, Science for Life Laboratory, Uppsala University, SE 75123 Uppsala, Sweden

2 Department of Molecular Pathology, Graduate School of Medicine, The University of Tokyo, Tokyo 113-0033, Japan

3 Department of Cell and Chemical Biology, Oncode Institute, Leiden University Medical Center, 2300 RC Leiden, The Netherlands phases TGF $\beta$ frequently stimulates tumor cell invasion and metastasis. Most of these functions are mediated through SMADs, which are the canonical intracellular transcriptional effectors of the TGF $\beta$ receptors. Activated SMADs form complexes with other DNA binding transcription factors to elicit cell-type-dependent responses. Cancers are characterized by tumor- and patient-specific de-regulation of multiple signaling pathways, and, in addition, generation of specific and altered interactions with the microenvironment relative to the normal tissue organization. Understanding the complex interplay of oncogenic signaling pathways, including antagonistic, cooperative, and synergistic effects, is critical to understand the nature of cancer cell phenotypes, and to enable more efficient and specific therapeutic intervention. The combined action of epidermal growth factor (EGF) and TGF $\beta$ signaling represents a classic example of oncogenic cooperation and contextdependence. TGF $\beta$ was initially discovered by its ability to induce normal rat kidney (NRK) cells to grow in soft agar in cooperation with TGF $\alpha$ or EGF $[1,2]$. In normal epithelial cells EGF induces proliferation, whereas TGF $\beta$ acts as a growth inhibitor, by inducing cell cycle arrest and 
apoptosis. However, both EGF and TGF $\beta$ can trigger epithelial-mesenchymal transition (EMT) and migratory responses in epithelial cells [3-7]. TGF $\beta$ can become a strong tumor promoter in cancer cells that have become insensitive to TGF $\beta$-induced growth inhibition by MYC activation and other cell cycle defects. In particular this is the case in the presence of additional pro-oncogenic signals, such as high levels of active EGFR, mutant RAS and WNT$\beta$-CATENIN signaling [4-7]. In specific circumstances, this may involve direct counteraction of TGF $\beta$ 's tumor suppressive effects by HER2 overexpression [8,9].

Signaling by TGF $\beta$ occurs via type I and type II serine/ threonine kinase receptors (TGF $\beta R I$ and TGF $\beta$ RII, respectively), which mainly propagate the signal through phosphorylation of the receptor-regulated (R-) SMAD proteins, i.e., SMAD2 and SMAD3 [10, 11]. Activated R-SMADs form complexes with common-partner (Co-) SMAD, i.e., SMAD4. These heteromeric complexes accumulate in the nucleus and control gene expression in a cell-type- and gene-specific manner. Essential for the specificity are the interactions of SMADs with lineage-determining and signal-driven transcription factors, chromatin-remodeling factors, co-activators, and co-repressors, which increase SMAD DNA binding and transactivating potential. In addition to these interactions, multiple other layers of regulation influence the intensity and duration of TGF $\beta$ signaling, and thereby define the specificity of the response [7, 12]. This fine-tuning involves amongst others various ubiquitin E3 ligases and non-SMAD signaling pathways, such as the PI3K-AKT-mTOR and MAPK pathways, which can be induced by TGF $\beta$ as well as other growth-regulatory stimuli $[4,12]$.

EGF receptor activation can potently trigger multiple kinase cascades, including the RAS-MAPK and the PI3KAKT pathways, and thereby enhance survival, proliferation, differentiation, and motility [3]. Cross-talk between EGFR and TGF $\beta$ signaling occurs at multiple levels, for instance via post-translational modification of the SMAD proteins $[4,5,13,14]$, and by induction of each other's ligands (HBEGF, TGF 1 1), which results in sustained activation of the MAPK and PI3K-AKT pathways [9]. However, the effects of this cross-talk on the interplay between SMAD proteins and SMAD-cooperating transcription factors in tumorpromotion are relatively unknown.

The members of the AP-1 family of transcription factors regulate gene expression in response to a large number of stimuli and pathways, including TGF $\beta$-SMAD and EGFRMEK-MAP kinase signaling. The "classical" AP-1 family is composed of dimers of JUN, JUNB or JUND, and FOS, FOSB, FOSL1 or FOSL2, which all exhibit specific functions in the control of cell proliferation and differentiation [15-22]. Certain AP-1 components have been implicated in tumor cell invasion [23-25], and in particular FOSL1 has been associated with breast cancer metastasis, EMT and cancer stemness [26-29]. Various JUN and FOS members have been found to interact with SMADs [25, 30, 31], and JUNB triggers activation of a TGF $\beta$-induced SMADdependent breast cancer invasion program [25, 32].

The p53 family member p63 is a transcriptional regulator of epithelial development and differentiation, acting as a common downstream effector of activated EGFR/RAS and TGF $\beta$ pathways, and playing an important role in primary breast cancers. p63 can be expressed in multiple different protein isoforms (TAp63 $\alpha / \beta / \gamma / \delta / \varepsilon$ and $\Delta \mathrm{Np} 63 \alpha / \beta / \gamma / \delta / \varepsilon)$, of which the $\Delta \mathrm{N}$ forms lack an intact transactivation (TA) domain. TAp63 and $\Delta$ Np63 isoforms can have dual, genespecific but opposite, effects on target genes [33], implying that their expression needs to be finely regulated during cancer initiation and progression. $\Delta \mathrm{Np} 63$ isoform is frequently overexpressed in human malignancies and can regulate oncogenic routes involved in the pathogenesis of breast carcinoma by contributing to proliferation, stemness and survival of breast tumors [34]. Previously, we demonstrated, on a genome-wide scale, that co-activation of RAS and TGF $\beta$ signaling via downregulation of mutant p53 can enhance binding of p63 to its genomic sites [35]. In this paper, we present novel mechanistic insight into the pro-oncogenic EGF-TGF $\beta$-p63-AP-1 interplay in breast cancer cells.

\section{Results}

\section{TGF $\beta$ requires co-stimulation of EGFR to induce a pro-invasive gene program in HER2 + and EGFR + breast cancer cells}

Using a 3D model of collagen-embedded spheroids of premalignant MCF10A human breast cancer cells, we previously found TGF $\beta$-SMAD signaling to induce breast cancer cell invasion by activating various invasionassociated genes, including matrix metallo-proteinases (MMPs) and WNT family members [25, 32, 36]. The T24 H-RAS-transformed MCF10A MII cells used in these studies are routinely cultured in the presence of EGF, insulin and other supplements, since parental MCF10A cells require growth factors and hormones to proliferate [37, 38]. Since both active RAS and EGFR signaling can influence TGF $\beta$-induced functions, we determined the pro-invasive effect of TGF $\beta$ in the 3D spheroid system in absence and presence of EGF. Surprisingly, TGF $\beta$ induced invasion only in the presence of EGF, whereas EGF had a weak invasive effect by itself (Fig. 1a). Moreover, TGF $\beta$-induced invasion in the presence of EGF was inhibited both by the EGFR kinase inhibitor lapatinib and by the TGF $\beta R I$ kinase (ALK5) inhibitor SB505124 (Fig. 1b). Similar results were obtained for the basal EGFR+ breast cancer cell line 

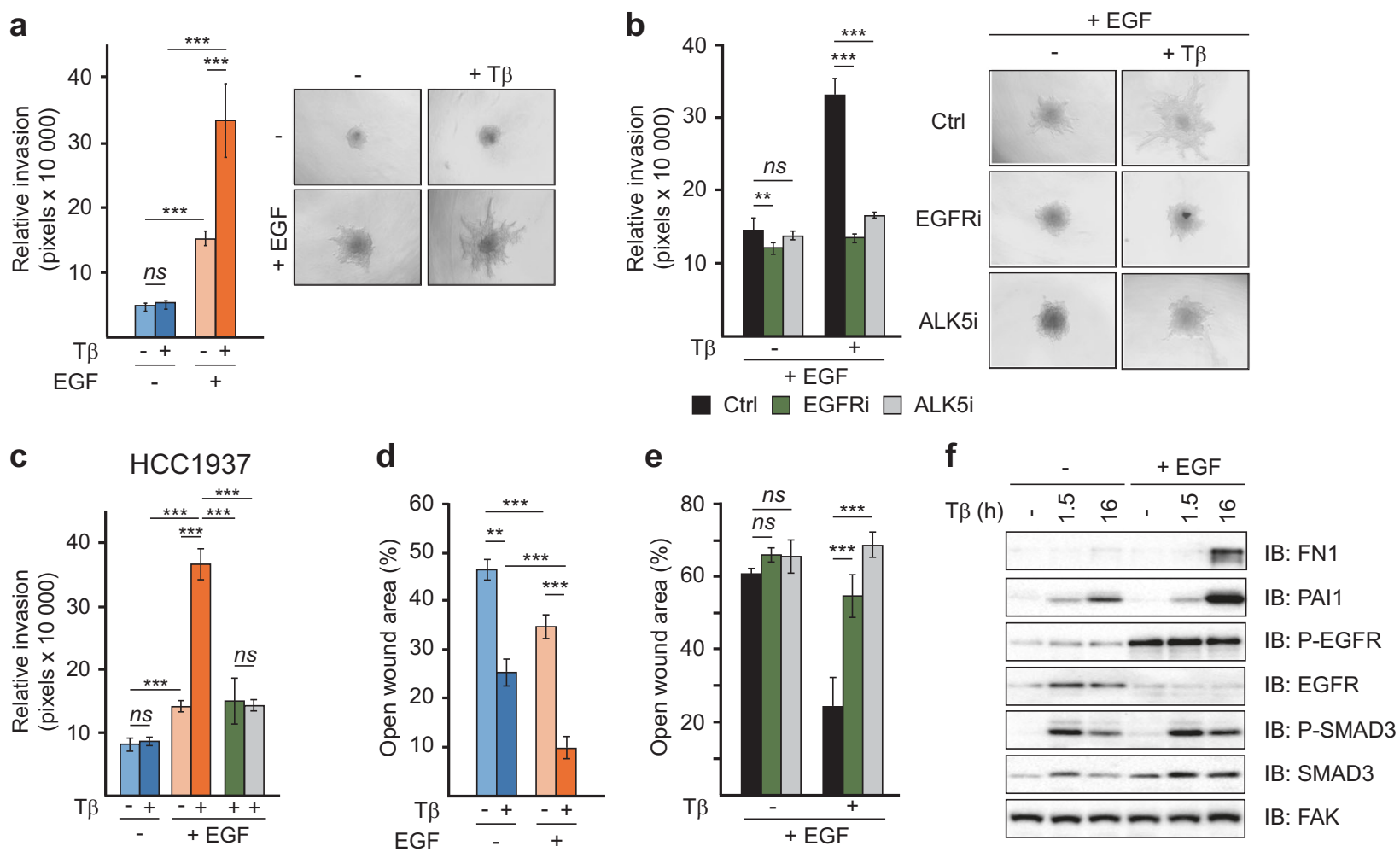

g
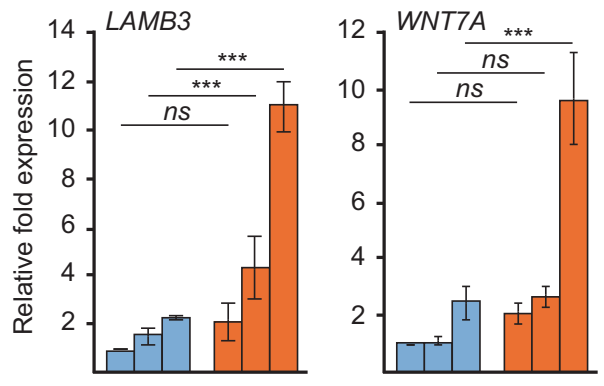

MCF10A MII

h

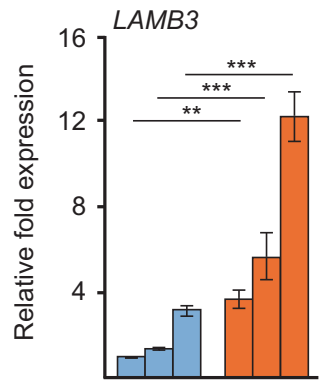

$\mathrm{T} \beta(\mathrm{h})$
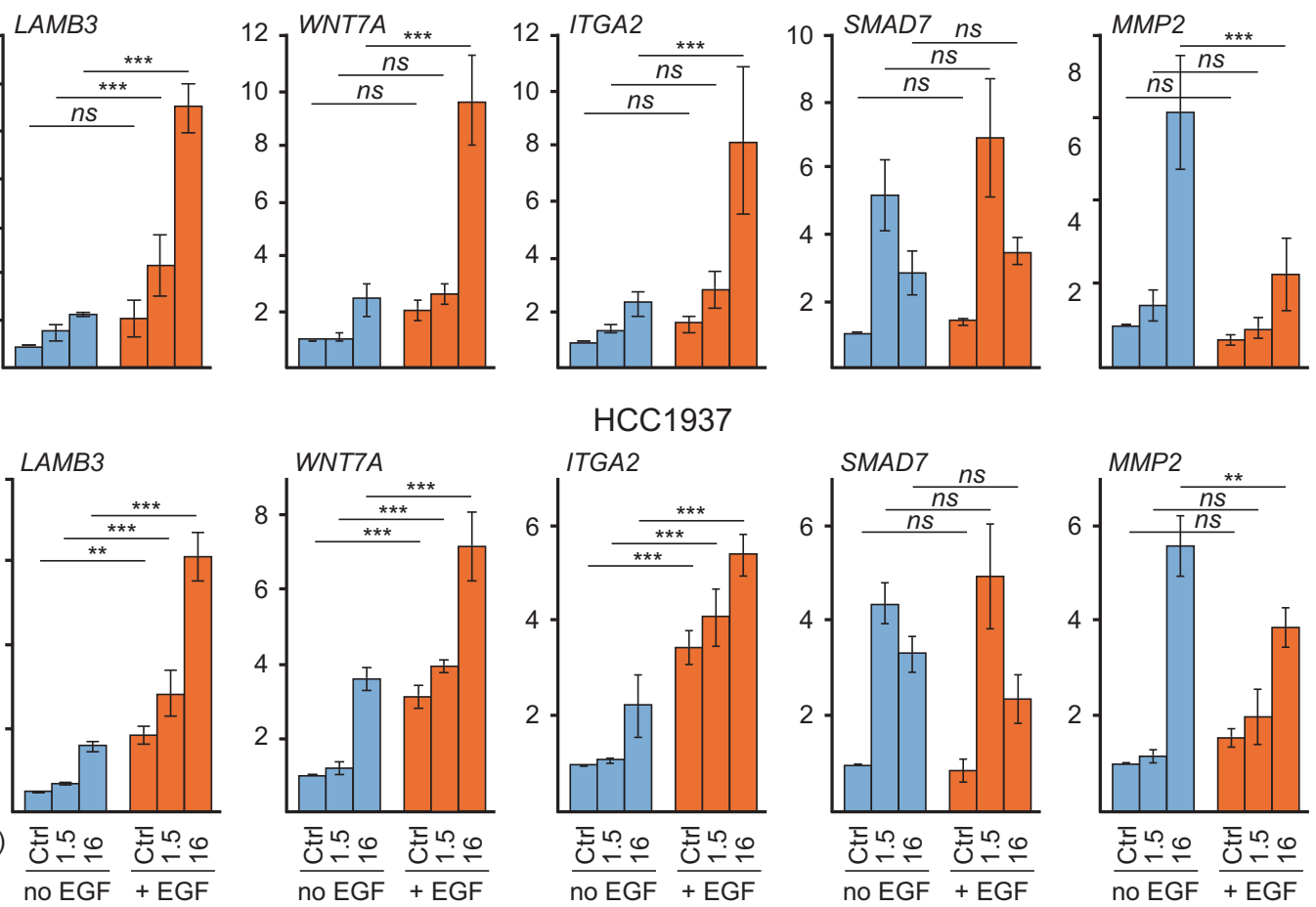

HCC1937
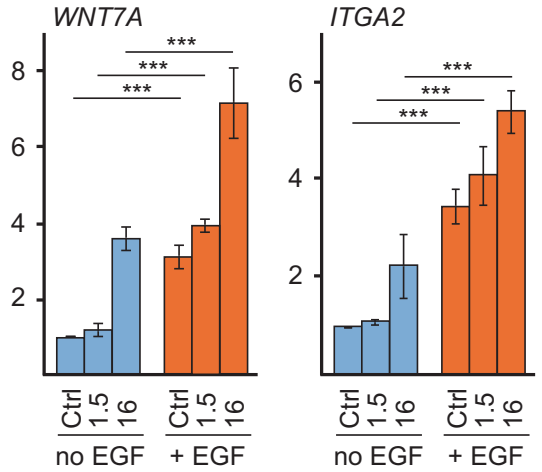


HCC1937 (Fig. 1c and Supplementary Fig. S1a). When analyzed for their migratory properties in 2D woundhealing assays, MCF10A MII cells were found to migrate most efficiently when both TGF $\beta$ and EGF were present (Fig. 1d and Supplementary Fig. S1b). The TGF $\beta$-induced migration in the presence of EGF was under these conditions also inhibited by either inhibition of the EGFR kinase or the TGFßRI kinase (Fig. 1e and Supplementary Fig. S1c). Analysis of some of the major TGF $\beta$-inducible proteins also showed dependence on EGF. Fibronectin 1 (FN1) 
Fig. 1 TGF $\beta$-induced invasion and migration requires EGFR activity. a Collagen-invasion of MCF10A MII spheroids in the presence or absence of $5 \mathrm{ng} / \mathrm{ml}$ TGF $\beta 1$ (T $\beta)$ and $20 \mathrm{ng} / \mathrm{ml} \mathrm{EGF}$, as indicated. Left: relative invasion was quantified as the mean area that the spheroids occupied $28 \mathrm{~h}$ after being embedded in collagen. Right: representative pictures of spheroids were taken $28 \mathrm{~h}$ after embedding. b The effects of the EGFR inhibitor lapatinib (EGFRi; $10 \mu \mathrm{M})$ and the TGF $\beta R I$ inhibitor SB505124 (ALK5i; $2.5 \mu \mathrm{M}$ ) on $5 \mathrm{ng} / \mathrm{ml}$ TGF $\beta 1$ induced collagen-invasion of MCF10A MII spheroids in the presence of $20 \mathrm{ng} / \mathrm{ml}$ EGF. Left: relative invasion was quantified as the mean area that the spheroids occupied $28 \mathrm{~h}$ after being embedded in collagen. Right: representative pictures of spheroids were taken $28 \mathrm{~h}$ after embedding. c Collagen-invasion of HCC1937 spheroids in the presence or absence of TGF 1 ( $5 \mathrm{ng} / \mathrm{ml})$, EGF $(20 \mathrm{ng} / \mathrm{ml})$, lapatinib (EGFRi) and SB505124 (ALK5i) as indicated, performed as described under $(\mathbf{a}, \mathbf{b})$. $\mathbf{a}-\mathbf{c}$ Statistics were calculated using one-way analysis of variance (ANOVA). The data were further analyzed using Tukey's multiple comparisons test. Data represent mean \pm SD $(n \geq 6$ spheroids per condition) and are representative of three independent experiments; $n s$, not significant, ${ }^{* *} P<0.01$, and $* * * P<0.001$. d Migration of MCF10A MII cells in the presence or absence of TGF $\beta$ and EGF measured by wound-healing (scratch) assays. MCF10A MII cells were incubated for $16 \mathrm{~h}$ in $0.2 \%$ FBS starvation medium in the presence or absence of $20 \mathrm{ng} / \mathrm{ml}$ EGF, and then treated with $5 \mathrm{ng} / \mathrm{ml}$ TGF $\beta 1$ as indicated. Migration was measured after $48 \mathrm{~h}$ by quantifying the percentage of open area left after scratching a confluent cell layer at $t=0$. e The effects of the EGFR inhibitor lapatinib $(1 \mu \mathrm{M})$ and the TGF $\beta R I$ inhibitor SB505124 $(2.5 \mu \mathrm{M})$ on TGF $\beta$ + EGF-induced migration of MCF10A MII cells measured by wound-healing (scratch) assays. Cells were incubated for $16 \mathrm{~h}$ in $0.2 \%$ FBS starvation medium in the presence of $20 \mathrm{ng} / \mathrm{ml}$ EGF before addition of $5 \mathrm{ng} / \mathrm{ml}$ TGF $\beta 1$ and/or inhibitors, as indicated. Migration was measured after $42 \mathrm{~h}$ by quantifying the percentage of open area left after scratching a confluent cell layer at $t=0$. d-e Statistics were calculated using one-way analysis of variance (ANOVA). The data were further analyzed using Tukey's multiple comparisons test. Data represent mean \pm SD $(n=8$ measurements per sample) and are representative of three independent experiments; $n s$, not significant, $* * P<0.01$, and $* * * P<0.001$. f Western blot analysis of TGF $\beta$-EGF cooperation. MCF10A MII cells were incubated for $16 \mathrm{~h}$ in starvation medium containing EGF, insulin, cholera toxin, hydrocortisone, $0.2 \% \mathrm{FBS}$, or in starvation medium lacking EGF $(20 \mathrm{ng} / \mathrm{ml})$, and subsequently treated with $5 \mathrm{ng} / \mathrm{ml}$ TGF $\beta 1$ for $0,1.5$, or $16 \mathrm{~h}$, as indicated and analyzed by immunoblotting. One of three independent experiments with similar results, is shown. $\mathbf{g}, \mathbf{h}$ EGF enables and enhances activation of a subset of TGF $\beta$ migration/ invasion genes. qRT-PCR analysis of TGF $\beta$ - and EGF-induced gene expression. MCF10A MII (g) or HCC1937 (h) cells were treated as in f. Statistics were calculated using one-way analysis of variance (ANOVA). The data were further analyzed using Tukey's multiple comparisons test. Results from four independent experiments are shown as mean $\pm \mathrm{SD} ; n s$, not significant, $* * P<0.01$, and $* * * P<0.001$.

was only induced by TGF $\beta$ in the presence of EGF in MII cells, and the late TGF $\beta$ induction of plasminogen activator inhibitor 1 (PAI1, encoded by the gene SERPINE1) was enhanced under these conditions. The induction of $\mathrm{C}$ terminal SMAD3 phosphorylation by TGF $\beta$ was not appreciably affected by EGF, and autophosphorylation of EGFR-Tyr1063 that was strongly enhanced by EGF, was not affected by TGF $\beta$ (Fig. 1f).

To investigate the mechanism by which EGFR signaling enables and potentiates TGF $\beta$-induced invasion and migration, we analyzed the effect of EGF on the expression of previously identified TGF $\beta$-inducible invasion genes [25, 32, 36]. In MII cells a subset of them, including $L A M B 3, I T G A 2, W N T 7 A, W N T 7 B$, and $M M P 10$, were induced by TGF $\beta$ only when EGF was present, whereas others, such as MMP2 and SNAII, were induced by TGF $\beta$ in the absence of EGF; other genes were hardly affected, such as COL7A1 and SMAD7 (Fig. 1g and Supplementary Fig. S1d). In the EGFR+ HCC1937 cells, and also in basallike EGFR + and HER2 + HCC1954 breast cancer cells, the presence of EGF strongly enhanced both the basal and TGF $\beta$-induced levels of subsets of these invasion genes, whereas HER2 + HCC202 cells showed similar result as MII cells (Fig. 1h and Supplementary Fig. S1e, f).

We next examined the effect of EGF on the binding of SMAD2/3 to representative SMAD binding regions, which we had previously identified by chromatin immunoprecipitation (ChIP) sequencing [32]. ChIP analysis in MCF10A MII cells showed that the TGF $\beta$-induced binding of SMAD2/3 to the LAMB3, WNT7B, and ITGA2 SMAD binding regions was strongly enhanced by EGF, whereas SMAD2/3 binding to the SMAD7 region was not appreciably affected, and the binding to $M M P 2$ was reduced (Supplementary Fig. S1g). These SMAD2/3 ChIP results thus correlate with the TGF $\beta$-induced mRNA levels of the respective genes in the presence and absence of EGF, and show that the effects of EGF on TGF $\beta$-dependent invasion/ migration genes are gene locus specific, and therefore may depend on the presence of specific transcription factors cooperating with SMADs. In summary, these result show that in multiple HER2 + and/or EGFR + breast cancer cell lines EGF selectively enables and/or potentiates activation of a subset of critical TGF 3 -SMAD inducible invasion/ migration-associated genes.

\section{EGFR can cooperate with TGF $\beta$ RI via the MEK-ERK pathway}

EGFR activates multiple downstream signaling pathways, including the RAF-MEK-ERK and the PI3K-AKT pathways, both of which cooperate with TGF $\beta$-SMAD-signaling and gene activation $[9,14]$. To examine the role of these pathways in TGF $\beta$-induced MII spheroid invasion in collagen in the presence of EGF, we used two different MEK inhibitors PD184352/CL-1040 and AZD6244 (Selumetinib), the PI3K inhibitor LY294002, and the AKT inhibitor MK-2206 and compared their effects with those of the EGFR and TGFßRI kinase inhibitors. Similar as in Fig. 1a, the TGF $\beta R I$ and EGFR kinase inhibitors completely counteracted TGF $\beta+$ EGF-induced invasion, whereas the PI3K and AKT inhibitors only had weak suppressive effects. Inhibition of the MEK-ERK pathway showed much stronger effects than TGF $\beta$ or EGFR kinase inhibition and 
completely blocked both basal and TGF $\beta$-induced invasion of MCF10A MII spheroids embedded in collagen in the presence of EGF (Fig. 2a and Supplementary Fig. S2a, b).

To validate these differential effects and verify the specificity of the inhibitors, we next analyzed the activity state of downstream targets of the involved pathways. As shown in Fig. 2b and Supplementary Fig. S2c, the TGFßRI kinase inhibitors SB505124 and LY364947 strongly inhibited the C-terminal phosphorylation of SMAD2 and SMAD3 induced after $1 \mathrm{~h}$ of TGF $\beta$-treatment, but not the levels of active, phosphorylated EGFR, ERK, AKT, and p70 S6 kinase. Conversely, lapatinib strongly reduced the autophosphorylation of EGFR, and partially reduced phosphoERK and the phospho-p70 S6K control, but did not affect C-terminally phosphorylated SMAD2 and SMAD3. In contrast, the MEK inhibitors PD184352 and AZD6244 completely inhibited the phosphorylation of the MEK substrate ERK (Fig. 2b and Supplementary Fig. S2c), but had no effects on the other targets. As expected, the AKT inhibitor MK-2206 completely reduced the (auto) phosphorylation of AKT and partially reduced the phosphorylation of p70 S6 kinase (Fig. 2b). The PI3K inhibitor LY294002 completely blocked the phosphorylation of p70 S6K and partially reduced the phosphorylation of AKT, but similar to the AKT inhibitor, did not affect ERK phosphorylation (Fig. 2b and Supplementary Fig. S2c). These results thus confirm the efficiency and pathway specificity of these inhibitors at the conditions used.

Interestingly, the two MEK inhibitors reduced the levels of phospho-ERK much stronger than the EGFR inhibitor, while the PI3K and AKT inhibitors had more potent effects on phospho-AKT and p70 S6K than EGFR inhibition (Fig. $2 \mathrm{~b}$ and Supplementary Fig. S2c). These observations suggest that EGFR is not the only upstream activator of MEKERK and PI3K-AKT in the mutant RAS expressing MII cells, and may also explain the very strong inhibitory effects of the MEK inhibitors on both basal and TGF $\beta$-induced invasion of MCF10A MII spheroids in EGF containing medium.

We next compared the effects of TGF $\beta$ RI, EGFR, MEKERK and PI3K/AKT inhibition on the EMT- and invasionassociated genes that in Fig. $1 \mathrm{~g}$ showed different TGF $\beta$-SMAD responses in the presence and absence of EGF. The TGF $\beta R I$, EGFR and MEK inhibitors, but not the PI3K or AKT inhibitors, strongly reduced the mRNA levels of LAMB3, WNT7A, and ITGA2 (Fig. 2c). In contrast, the induction of $M M P 2$, which was reduced by EGF (Fig. 1g), was inhibited by the TGFßRI inhibitor, but enhanced rather than suppressed by the EGFR and MEK inhibitors (Fig. 2c). Moreover, similar to ERK phosphorylation and TGF $\beta$-induced collagen-invasion, the induction of LAMB3, WNT7A and ITGA2 by TGF $\beta$ in the presence of EGF was more strongly inhibited by MEK inhibition than by EGFR inhibition.
Together, these results indicate that the EGFR-MEK-ERK arm can play a critical role in TGF $\beta$-induced invasion by enabling and/or strongly potentiating TGF $\beta$-induction of selective invasion/migration-associated genes.

\section{EGFR signaling enables and potentiates TGF $\beta$ induction of AP-1 (JUN/FOS)}

We previously found that TGF $\beta$-induction of the EGFRdependent invasion-associated genes identified in Fig. $1 \mathrm{~g}$ and Supplementary Fig. S1d requires AP-1-dependent SMAD2/3 recruitment $[25,32]$. We therefore next examined the effects of EGF on TGF $\beta$ induction of AP- 1 components. As shown in Fig. 3a, b and Supplementary Fig. $\mathrm{S} 3 \mathrm{a}, \mathrm{b}$, both the basal and TGF $\beta$-induced levels of JUN, JUNB, FOSL1 and/or FOS, FOSB, FOSL2 were strongly enhanced in the presence of EGF in MCF10A MII, HCC1937, HCC1954 and HCC202 cells. We also analyzed the chromatin binding of the two key AP-1 components JUNB and FOSL1 in cells treated with the combination of EGF and TGF $\beta$ vs TGF $\beta$ only. As shown in Supplementary Fig. S3c, d, combined EGF and TGF $\beta$ treatment resulted in increased binding of JUNB and/or FOSL1 to the SMAD binding regions of $L A M B 3, W N T 7 B$, and ITGA2.

When analyzed on the mRNA level the differences in TGF $\beta$ inducibility between the JUN and FOS family members were striking. In the absence of EGF, both JUN and $J U N B$ were efficiently induced by $1.5 \mathrm{~h}$ treatment with TGF $\beta$, but FOS, FOSB and FOSL1 were not. However, EGF increased the basal mRNA levels of FOS and FOSL1 (Fig. 3c). Interestingly, ChIP-qPCR analysis showed that EGF strongly enhanced TGF 3 -induced binding of SMAD2/ 3 to the FOS and FOSB loci, while having much less effect on the TGF $\beta$-induced binding of SMAD2/3 to the JUNB gene (Supplementary Fig. S3e).

To further examine the regulation of AP-1 by TGF $\beta$ and EGF signaling, we compared the effects of TGF $\beta R I$, EGFR, MEK, AKT and PI3K inhibition. Inhibition of TGF $\beta R I$ counteracted the induction by $6 \mathrm{~h}$ of TGF $\beta$ treatment of the AP-1 components FOS, FOSB, FOSL2, JUN and JUNB, in the presence of EGF (Fig. 3d), which is in line with our previous findings [25]. EGFR inhibition by lapatinib counteracted the TGF $\beta$-induced effects on these proteins as well, and, strikingly, reduced the levels of FOS and FOSL1 even below their basal levels. The MEK inhibitor suppressed the levels of the four FOS family members more efficiently than lapatinib, similar to their effects on phospho-ERK in Fig. 2b. MEK inhibition also completely blocked TGF $\beta$-induction of JUNB, but only had a weak suppressing effect on JUN. In contrast, inhibition of PI3K and AKT did not reduce the TGF $\beta$-induced effects on JUNB and the FOS family, but like the MEK inhibitor partially reduced the levels of JUN (Fig. 3d). In line with 
a
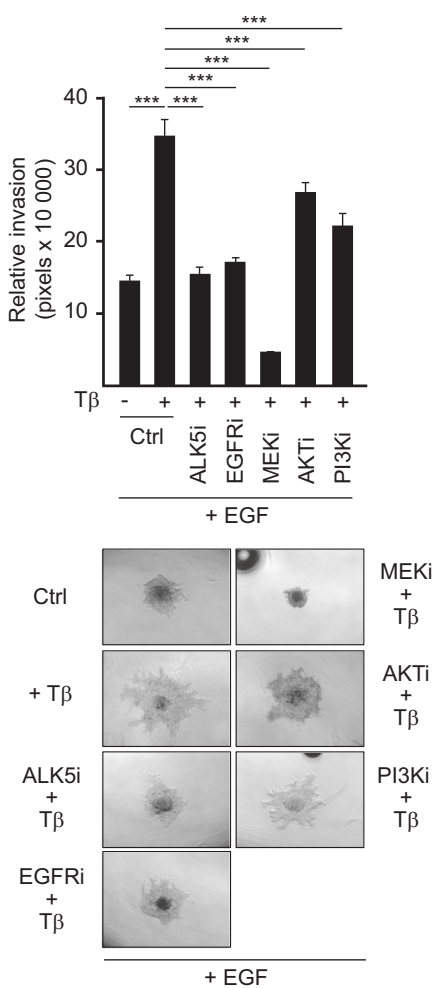

b

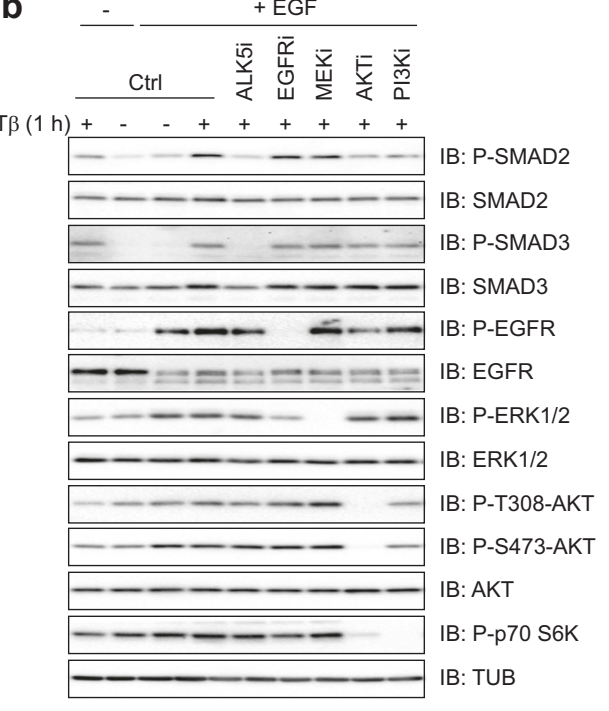

C
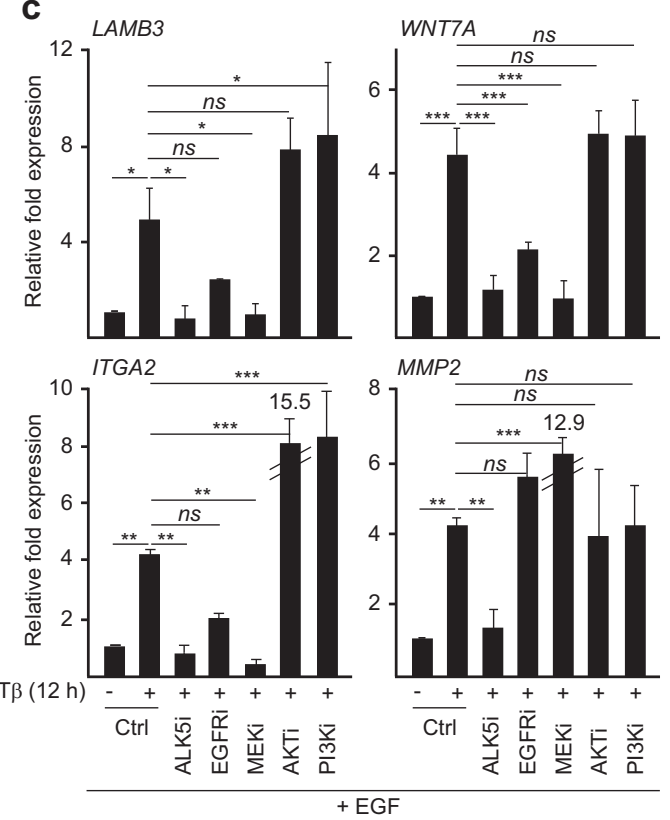

Fig. 2 EGFR cooperates with TGFßRI via the MEK-ERK pathway. a Comparison of the kinase inhibitors SB505124 (ALK5i), lapatinib (EGFRi), AZD6244 (MEKi), MK-2206 (AKTi), and LY294002 (PI3Ki) on TGF 1 -induced collagen-invasion of MCF10A MII spheroids in the presence of EGF $(20 \mathrm{ng} / \mathrm{ml})$. Top: relative invasion was quantified as the mean area that the spheroids occupied $26 \mathrm{~h}$ after being embedded in collagen. Statistics were calculated using oneway analysis of variance (ANOVA). The data were further analyzed using Dunnett's multiple comparisons test and compared with the results from cells treated with TGF $\beta 1(5 \mathrm{ng} / \mathrm{ml})$ alone. Data represent mean $\pm \mathrm{SD}(n \geq 6$ spheroids per condition) and are representative of three independent experiments; $n s$, not significant, $* * * P<0.001$. Bottom: representative pictures of spheroids were taken $26 \mathrm{~h}$ after embedding. b Immunoblot validation of kinase inhibitor specificity. MCF10A MII cells were incubated for $16 \mathrm{~h}$ in $0.2 \%$ FBS starvation medium with or without EGF $(20 \mathrm{ng} / \mathrm{ml})$ before addition of the same kinase inhibitors as in (a), or control. $15 \mathrm{~min}$ later TGF $\beta 1(5 \mathrm{ng} / \mathrm{ml})$ was added and incubation prolonged for $1 \mathrm{~h}$. One of three independent experiments with similar results, is shown. $\mathbf{c}$ qRT-PCR analysis of TGF $\beta$ and EGF-induced gene expression. MCF10A MII cells were incubated for $16 \mathrm{~h}$ in $0.2 \%$ FBS starvation medium with EGF (20 ng/ $\mathrm{ml})$ before addition of the indicated kinase inhibitors or DMSO (control). TGF $\beta 1(5 \mathrm{ng} / \mathrm{ml})$ was added $15 \mathrm{~min}$ later and incubation prolonged for $12 \mathrm{~h}$. Statistics were calculated using one-way analysis of variance (ANOVA). The data were further analyzed using Dunnett's multiple comparisons test and compared with the results from cells treated with TGF $\beta 1(5 \mathrm{ng} / \mathrm{ml})$ alone. Results from three independent experiments are shown as mean $\pm \mathrm{SD} ; n s$, not significant, $* P$ $<0.05, * * P<0.01$, and $* * * P<0.001$. 
a

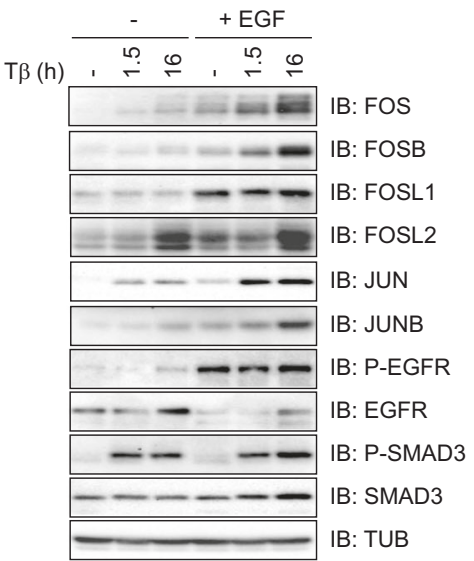

HCC1937

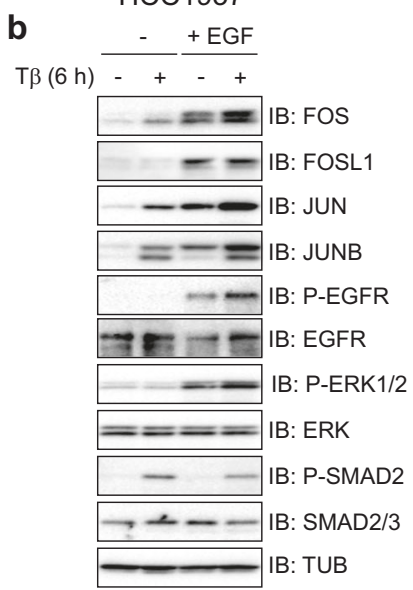

C
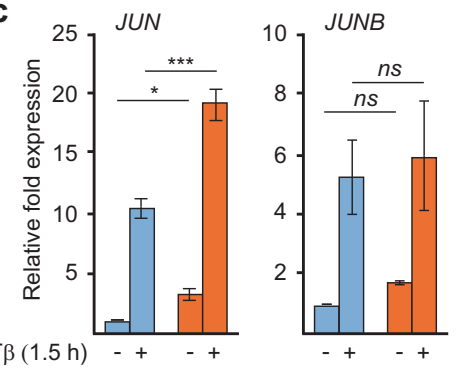

d

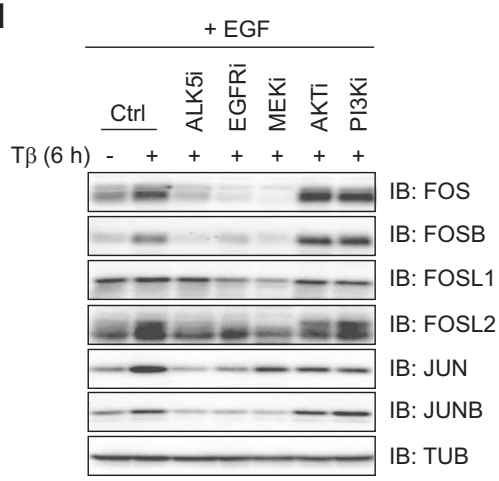

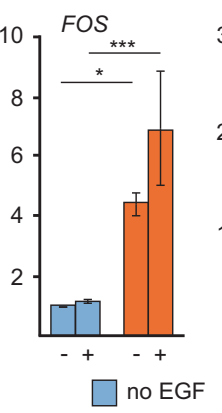
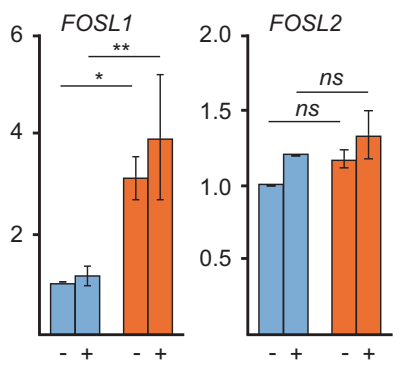

e

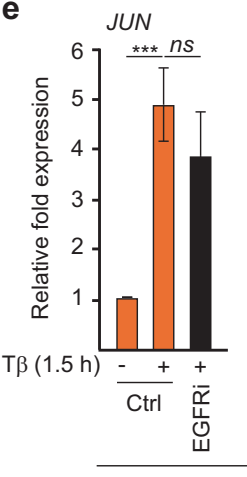

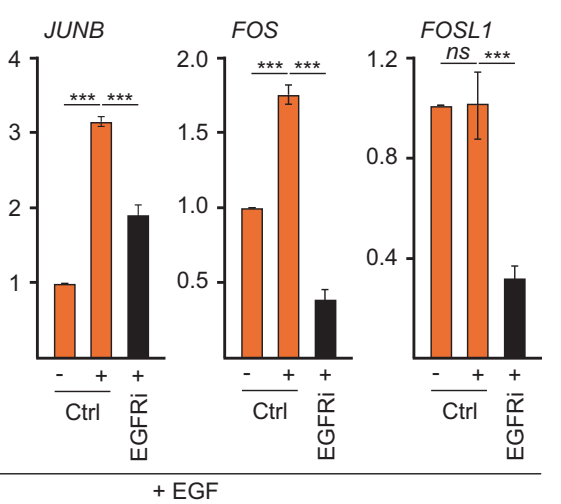

Fig. 3 EGFR-MEK signaling enables TGF $\beta$ induction of FOS family components. a Immunoblot analysis of TGF $\beta$ - and EGFinduced AP-1 components. MCF10A MII cells were incubated for $16 \mathrm{~h}$ in $0.2 \%$ FBS starvation medium with or without EGF $(20 \mathrm{ng} / \mathrm{ml})$ and subsequently treated with $5 \mathrm{ng} / \mathrm{ml}$ TGF $\beta 1$ for $0,1.5$, or $16 \mathrm{~h}$, as indicated. One of three independent experiments with similar results, is shown. b Immunoblot analysis of TGF $\beta$ - and EGF-induced AP-1 components. HCC1937 cells were incubated for $16 \mathrm{~h}$ in $0.2 \%$ FBS starvation medium with or without EGF $(20 \mathrm{ng} / \mathrm{ml})$ and subsequently treated with $5 \mathrm{ng} / \mathrm{ml}$ TGF $\beta 1$ for $6 \mathrm{~h}$ as indicated. One of three independent experiments with similar results, is shown. (c) qRT-PCR analysis of TGF $\beta$ - and EGF-induced mRNA for JUN and FOS family members. MCF10A MII cells were treated as in (a). Statistics were calculated using one-way analysis of variance (ANOVA). The data were further analyzed using Tukey's multiple comparisons test. Results from three independent experiments are shown as mean $\pm \mathrm{SD}$; $n s$, not significant, $* P<0.05$, $* * P<0.01$, and $* * * P<0.001$. d The

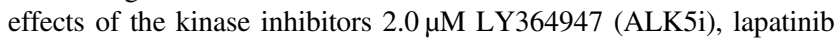

(EGFRi), AZD6244 (MEKi), MK-2206 (AKTi), and LY294002 (PI3Ki) on TGF $\beta$ - and EGF-induced AP-1 components. MCF10A MII cells were incubated for $16 \mathrm{~h}$ in $0.2 \%$ FBS starvation medium with EGF $(20 \mathrm{ng} / \mathrm{ml})$, before addition of the indicated kinase inhibitors or DMSO (control). $15 \mathrm{~min}$ later TGF $\beta 1(5 \mathrm{ng} / \mathrm{ml})$ was added and incubation prolonged for $6 \mathrm{~h}$ and cells were then analyzed by immunoblotting. One of three independent experiments with similar results, is shown. e qRT-PCR analysis of the effect of EGFR inhibition on TGF $\beta$ - and EGF-induced JUN and FOS mRNAs. MCF10A MII cells were incubated for $16 \mathrm{~h}$ in $0.2 \%$ FBS starvation medium with EGF $(20 \mathrm{ng} / \mathrm{ml})$ before addition of lapatinib (EGFRi) or DMSO (control). $15 \mathrm{~min}$ later TGF $\beta 1(5 \mathrm{ng} / \mathrm{ml})$ was added and incubation prolonged for $1.5 \mathrm{~h}$. Statistics were calculated using one-way analysis of variance (ANOVA). The data were further analyzed using Dunnett's multiple comparisons test and compared with the results from cells treated with TGF $\beta 1$ alone. Results from four independent experiments are shown as mean $\pm \mathrm{SD} ; n s$, not significant, $* * * P<0.001$. 
these data, the EGFR kinase inhibitor strongly reduced the $F O S$ and FOSL1 mRNA levels induced by TGF $\beta$ and EGF. The decrease on JUNB mRNA expression by EGFR kinase inhibitor was less pronounced while there was no significant effect on JUN mRNA levels (Fig. 3e). Together, these results indicate that EGFR signaling enables and potentiates induction of AP-1 (JUN/FOS) by TGF $\beta$ both at the protein and mRNA level.

\section{p63 is critical for EGFR-, JUN/FOS- and TGF $\beta / S M A D-$ mediated invasion and gene activation}

p63 has recently been shown to control epithelial stemness and cell fate specification [34], and its expression has been linked to basal-like breast cancers in correlation with additional basal epithelial markers [33]. Previous work by us and others showed that signaling by EGFR and its ligand HB-EGF can be controlled by p63- and/or JUN-mediated activation of the EGFR and HB-EGF genes [35, 39, 40]. Moreover, co-activation of RAS and TGF $\beta$ signaling in $\mathrm{HaCaT}$ keratinocytes enhances binding of p63 to its genomic sites via downregulation of mutant p53 [35]. This prompted us to investigate the putative mechanistic involvement of p63 in the TGF $\beta$ - EGF cooperation. We first analyzed the role of p63 in MCF10A MII cells, which express wildtype p53, and like HCC1954 and HCC1937 cells, essentially only the $\Delta \mathrm{Np} 63 \alpha$ isoform [41-43]. Interestingly, knockdown of p63 strongly reduced the expression of the pro-invasive TGF $\beta$ and AP-1 target genes, LAMB3, WNT7A, ITGA2, and MMP10, whereas p63 knockdown enhanced the expression of MMP2 and SNAII (Figs. 1g, 4a and Supplementary Fig. S1d and S4a). Similar results were obtained in HCC1954 cells (Fig. 4b) and the parental nononcogenic MCF10A MI cells, which do not contain active oncogenic RAS (Supplementary Fig. S4b). Knockdown of p63 also suppressed EGF- and TGF $\beta$-dependent invasion of MCF10A MII spheroids in collagen (Fig. 4c). EGF- and TGF $\beta$-induced recruitment of SMAD2/3 to the $L A M B 3$, $W N T 7 B$, and ITGA2 gene loci was suppressed by p63 knockdown as well, whereas SMAD2/3 binding to the MMP2 locus was not affected (Fig. 4d). These results thus strongly suggest that p63 is essential for the pro-invasive SMAD-AP-1 program in these HER2+ and/or EGFR+ breast cancer cells, which may involve binding of p63 to SMAD and AP-1 binding regions [35]. Indeed, endogenous p63 was found to interact with both endogenous SMAD2/3 and JUNB in MCF10A MII cells (Fig. 4e), and EGF treatment was found to increase the binding of p63 to the $L A M B 3$ and ITGA2 gene loci (Supplementary Fig. S4c).

To investigate further the mechanism by which p63 enables and/or enhances activation of the SMAD-AP-1 invasion program by TGF $\beta$ and EGF, we analyzed its effect on AP-1 and EGFR pathway components. As shown in
Fig. 5a, the levels of TGF $\beta$ - and EGF-inducible FOS and JUN members were suppressed upon p63 knockdown, as were the levels of EGFR, auto-phosphorylated EGFR and active phosphorylated ERK1/2 MAPK. In contrast, no effect was observed on the total levels of ERK or on TGF $\beta$-induced phosphorylation of SMAD3. Similar results were obtained upon transfection with $\Delta$ Np63-specific siRNA in MII, and MI cells (Fig. 5b and Supplementary Fig. S5a), and in HCC1954 cells (Fig. 5c). mRNA analysis showed that p63 knockdown in particular reduced the levels of FOS, FOSL1, and FOSL2 in MII cells (Fig. 5d), and of FOSL1 in HCC1954 cells (Supplementary Fig. S5b). Knockdown of p63 also reduced the mRNA levels of EGFR and HB-EGF in MCF10A MII cells (Fig. 5e). In line with the putative role of p63 in SMAD and AP-1-induced transcription, p63 was found to bind to the FOS, FOSB, FOSL1, $E G F R$ and $H B E G F$ gene loci (Fig. 5f). We conclude from these results that p63 can enable and potentiate the EGFRand AP-1-dependent TGF $\beta$ invasion/migration program by activating multiple AP-1 and EGFR pathway components.

Because both p63 and EGFR strongly enhanced the basal and TGF $\beta$-induced levels of FOS mRNA and protein, which can stabilize JUN members [19, 20], we next examined whether ectopic overexpression of FOS can bypass the requirement of p63 in MCF10A MII cells. Indeed, MII cells stably infected with a Flag-FOS lentiviral vector carried increased levels of phosphorylated active EGFR and ERK compared with control MII cells upon p63 knockdown, and also contained higher levels of TGF $\beta$-induced JUN and JUNB (Fig. 6a). Moreover, ectopic overexpression of FOS counteracted the decrease in the TGF $\beta$-induced mRNA levels of LAMB3, WNT7A, ITGA2 and SERPINE1 after p63 depletion (Fig. 6b).

In summary, these results show that $\triangle \mathrm{Np} 63$ is necessary for the activation of the EGFR-, and AP-1-dependent invasion gene program induced by TGF $\beta$ in multiple breast cancer cell lines. Moreover, by enhancing the levels of EGFR, HB-EGF, JUN and, in particular, FOS family members, $\triangle \mathrm{Np} 63$ can enable sustained activation of the pro-oncogenic gene program induced by SMADs and AP-1 in HER2+ and/or EGFR + breast cancer cells.

\section{Discussion}

TGF $\beta$ has a biphasic role in breast tumor progression $[7,13]$. In the early stages, TGF $\beta$-SMAD signaling inhibits cell growth and thus acts as a tumor suppressor. In late stage tumors, TGF $\beta$ usually functions as a tumor promoter, e.g., by stimulating EMT, i.e., trans-differentiation of epithelial cells to cells with more mesenchymal characteristics, and invasive and metastatic potential. These tumor cells have escaped TGF $\beta$-induced growth inhibitory and apoptotic 

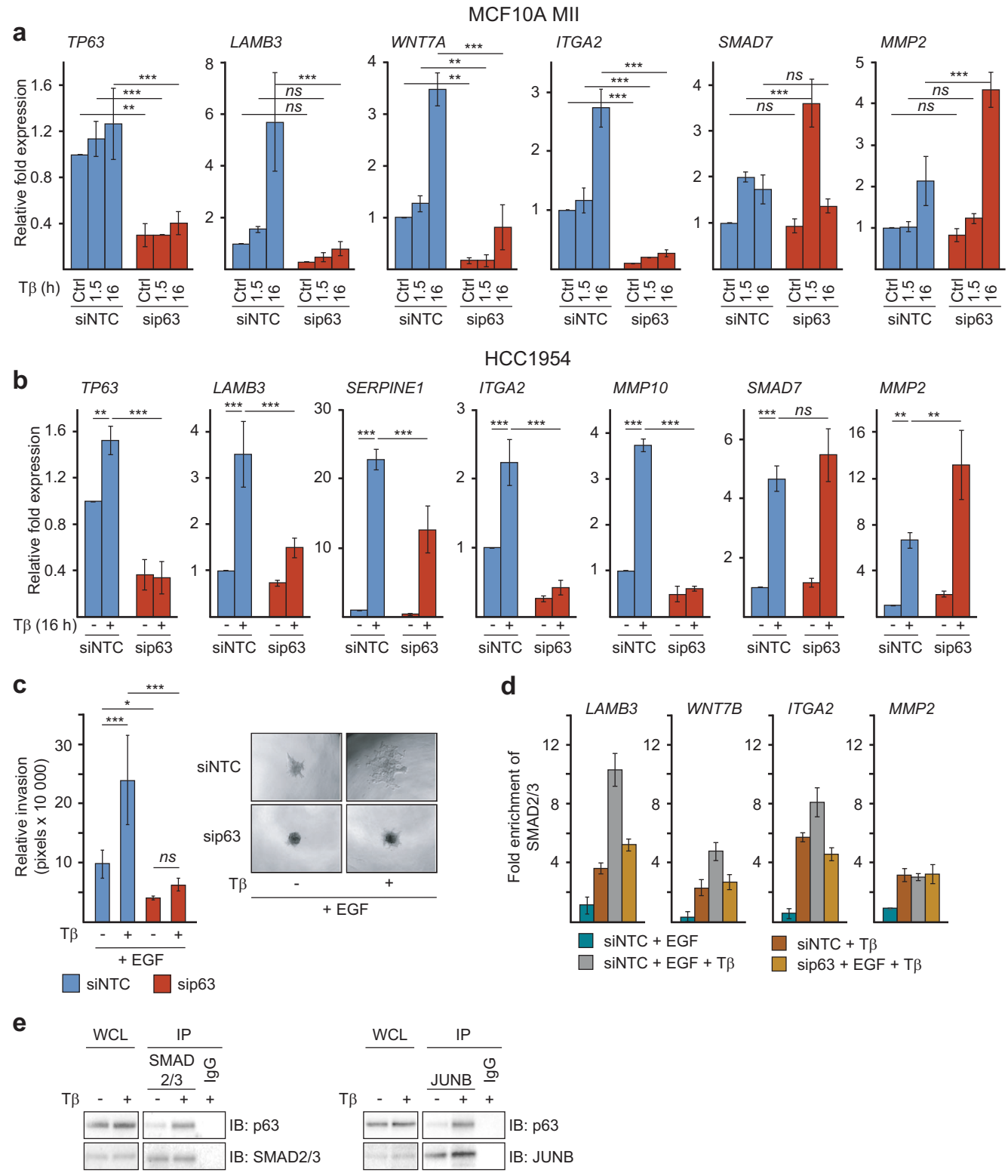

Fig. 4 p63 is essential for the pro-invasive SMAD-AP-1 program. a qRT-PCR analysis to investigate the role of p63 in TGF $\beta$ + EGFinduced gene expression. MCF10A MII cells were transfected with non-targeting control (siNTC) or specific p63 siRNA, serum-starved for $16 \mathrm{~h}$, and stimulated for 1.5 or $16 \mathrm{~h}$ with TGF $\beta 1(5 \mathrm{ng} / \mathrm{ml})$, as indicated. Statistics were calculated using one-way analysis of variance (ANOVA). The data were further analyzed using Tukey's multiple comparisons test. Results from four independent experiments are shown as mean $\pm \mathrm{SD} ; n s$, not significant, $* * P<0.01$, $* * * P<0.001$. b qRT-PCR analysis to investigate the effect of p63 depletion on TGF $\beta+$ EGF-induced target genes. HCC1954 cells were transfected with non-targeting control (siNTC) or specific p63 siRNA, serumstarved for $16 \mathrm{~h}$, and stimulated for 1.5 (SMAD7) or $16 \mathrm{~h}$ with TGF 1 $(5 \mathrm{ng} / \mathrm{ml})$, as indicated. Statistics were calculated using one-way analysis of variance (ANOVA). The data were further analyzed using Dunnett's multiple comparisons test and compared with the results from cells transfected with non-targeting control (siNTC) and treated with TGF $\beta 1(5 \mathrm{ng} / \mathrm{ml})$. Results from three independent experiments are shown as mean $\pm \mathrm{SD} ; * * P<0.01$, and $* * * P<0.001$. c Effect of p63 knockdown on collagen-invasion of MCF10A MII spheroids in the presence or absence of $5 \mathrm{ng} / \mathrm{ml}$ TGF $\beta 1$ and $20 \mathrm{ng} / \mathrm{ml}$ EGF, as indicated. Cells were transfected with non-targeting control (siNTC) or specific p63 siRNA before spheroid formation. Left: relative invasion was quantified as the mean area that the spheroids occupied $24 \mathrm{~h}$ after being embedded in collagen. Statistics were calculated using one-way analysis of variance (ANOVA). The data were further analyzed using Tukey's multiple comparisons test. Data represent mean \pm SD $(n \geq$ 6 spheroids per condition) and are representative of three independent experiments; $n s$, not significant, $* P<0.05$, and $* * * P<0.001$. Right: representative pictures of spheroids were taken $24 \mathrm{~h}$ after embedding. d The effect of p63 knockdown on SMAD2/3 recruitment by TGF $\beta$ and EGF. ChIP-qPCR showing SMAD2/3 binding to the indicated gene loci in MCF10A MII cells transfected with non-targeting control (siNTC) or specific p63 siRNA, serum-starved with or without EGF $(20 \mathrm{ng} / \mathrm{ml})$, and stimulated for $6 \mathrm{~h}$ with $5 \mathrm{ng} / \mathrm{ml}$ TGF $\beta 1(5 \mathrm{ng} / \mathrm{ml})$ or untreated, as indicated. One of two independent experiments with similar results, is shown. e p63 interaction with SMAD2/3 and JUNB. MCF10A MII cells grown in the presence of EGF $(20 \mathrm{ng} / \mathrm{ml})$ were stimulated with TGF $\beta$ ( $5 \mathrm{ng} / \mathrm{ml}, 45 \mathrm{~min}$ ) or not, and whole cell lysates (WCL) were immunoprecipitated (IP) with JUNB or SMAD2/3 specific antibodies, or IgG control, and analyzed by immunoblotting. One of three independent experiments with similar results, is shown. 
a

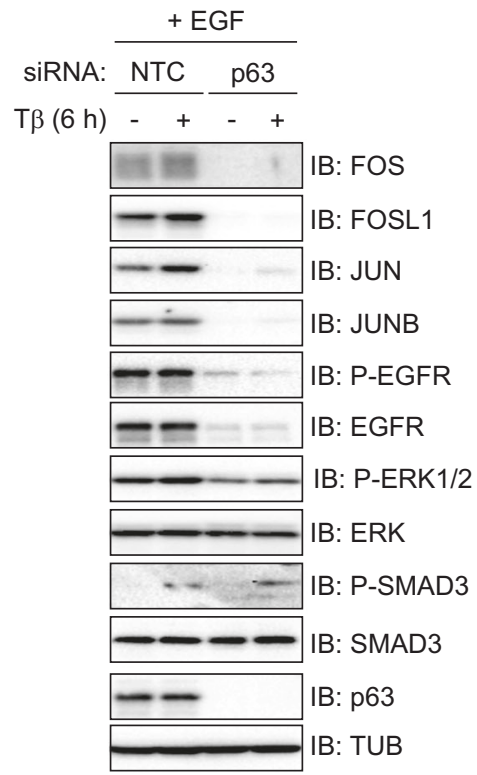

b

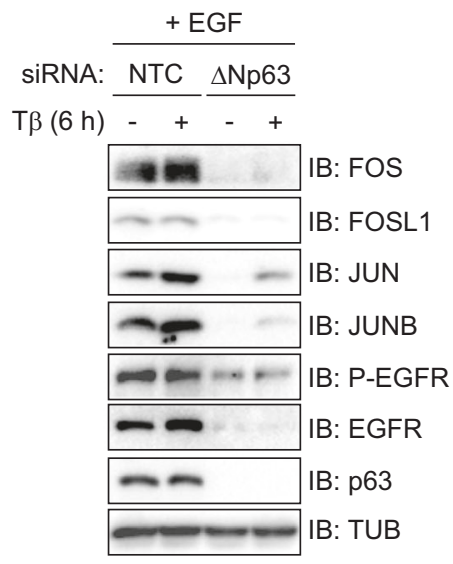

C

\section{HCC1954}

\begin{tabular}{rll} 
& \multicolumn{2}{c}{+ EGF } \\
siRNA: & $\frac{\text { NTC }}{\text { TB }(6 \mathrm{~h})}$ & $\mathrm{p} 63$ \\
\hline & + & $-\quad+$
\end{tabular}

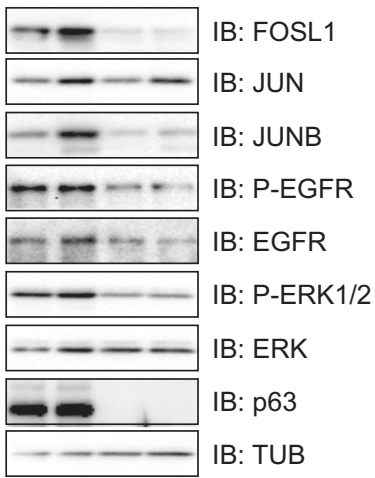

d

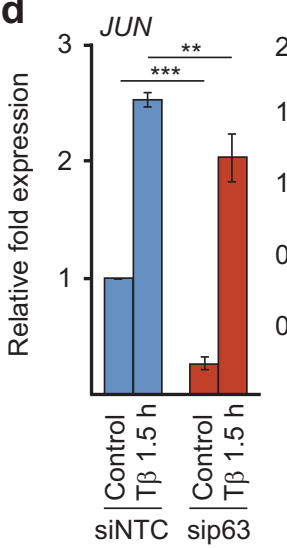

JUNB

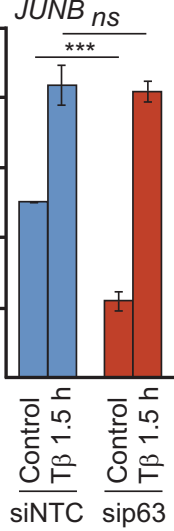

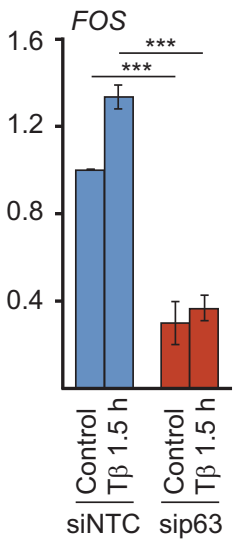
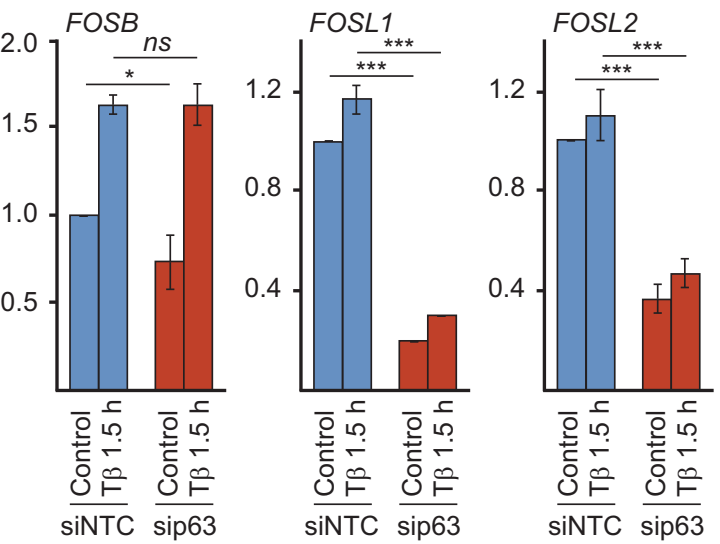

e
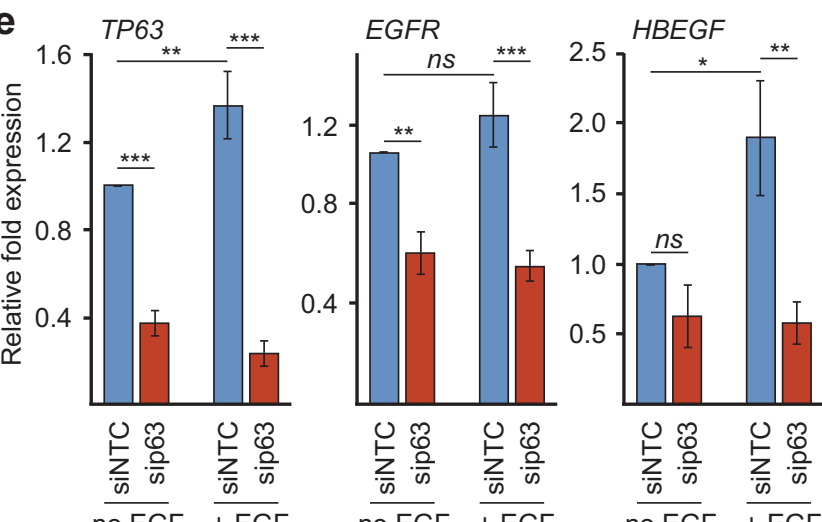

f

$\alpha-\lg G$

$\alpha-p 63$

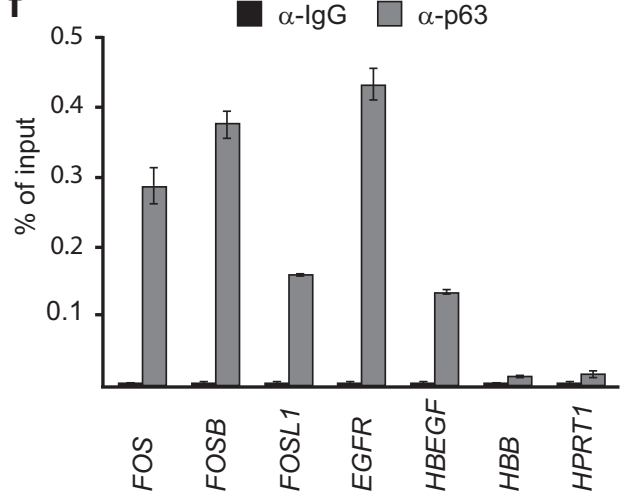

Fig. 5 p63 is essential for JUN/FOS, EGFR and HB-EGF expression. The effect of p63 knockdown on TGF $\beta$ - and EGF-induced AP-1 and EGFR pathway components. MCF10A MII (a, b) and HCC1954 (c) cells were transfected with non-targeting control (siNTC), p63 siRNA, or $\Delta$ Np63-specific siRNA, serum-starved for $16 \mathrm{~h}$, stimulated for $6 \mathrm{~h}$ with $5 \mathrm{ng} / \mathrm{ml}$ TGF $\beta 1$ or untreated, and analyzed by immunoblotting. One of three experiments with similar results, is shown. $\mathbf{d}$ and $\mathbf{e}$ MCF10MII cells were treated as in (a), stimulated with
TGF $11(5 \mathrm{ng} / \mathrm{ml})$ for $1.5 \mathrm{~h}(\mathbf{d})$ or $6 \mathrm{~h}(\mathbf{e})$, or untreated, and analyzed by qRT-PCR analysis. Statistics were calculated using one-way analysis of variance (ANOVA). The data were further analyzed using Tukey's multiple comparisons test. Results from three independent experiments are shown as mean $\pm \mathrm{SD} ; n s$, not significant, $* P<0.05, * * P<0.01$, and $* * * P<0.001$. f ChIP-qPCR showing p63 binding to the indicated gene loci in MCF10A MII cells. One of two independent experiments with similar results, is shown. 


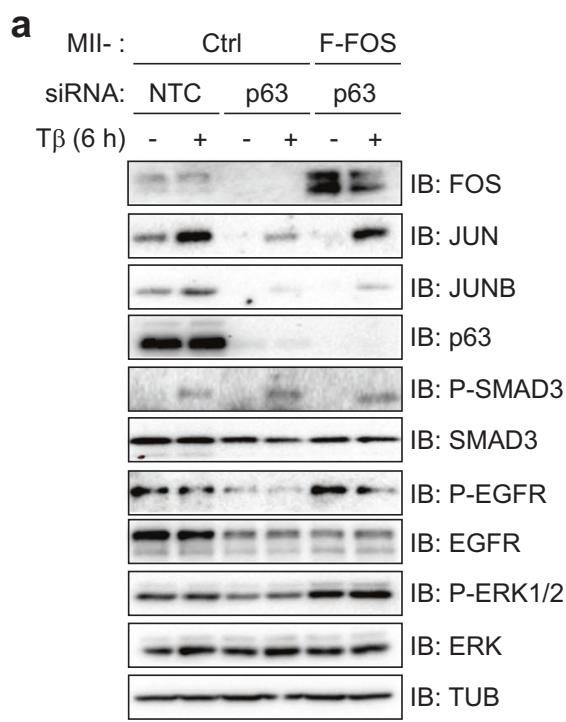

b
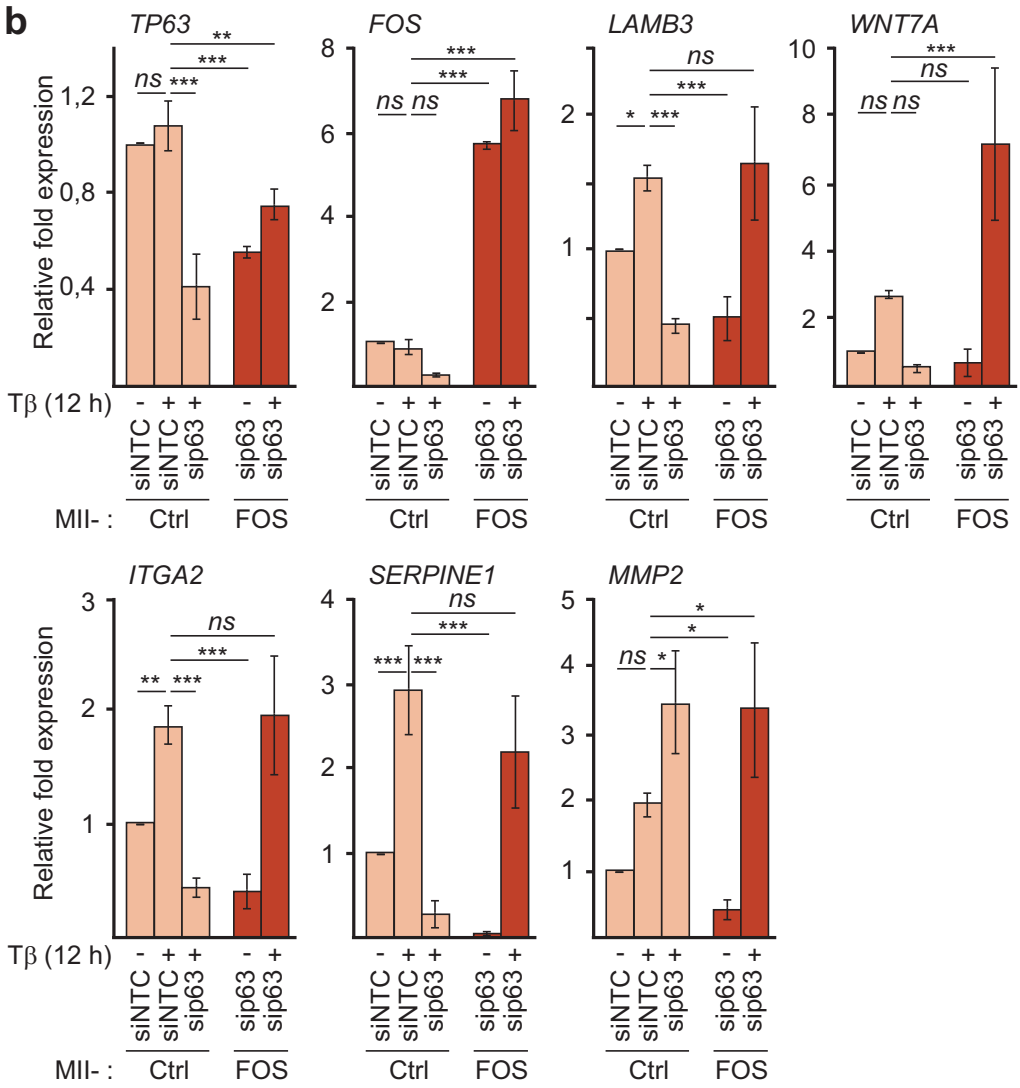

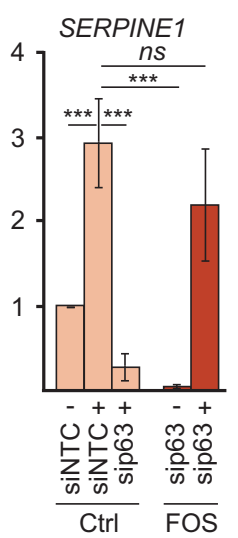

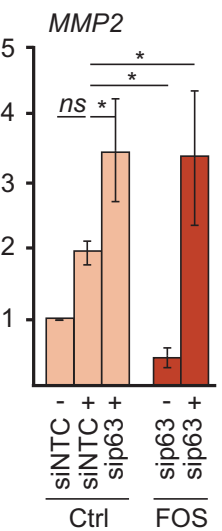

C

TGF $\beta$ without $\triangle N p 63$

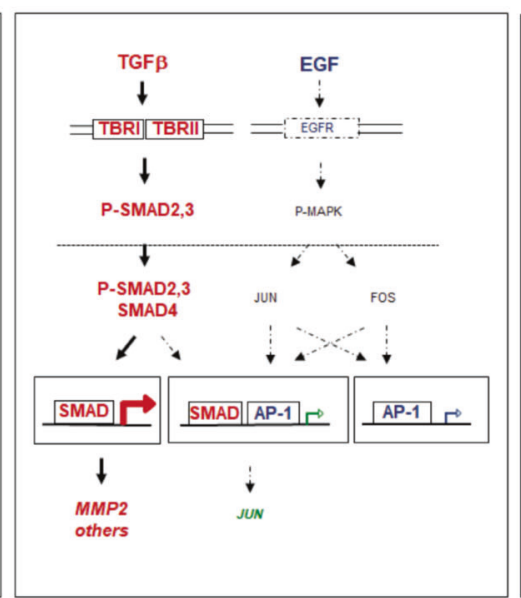

TGF $\beta$ with $\triangle \mathrm{Np} 63$ and EGF

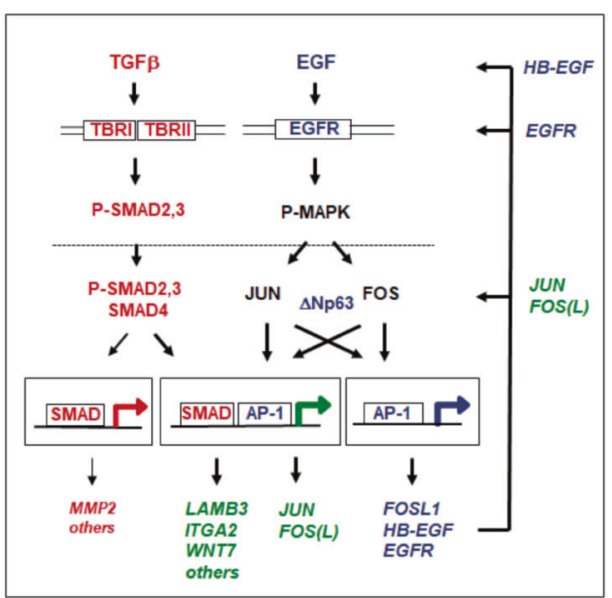

responses, but have retained or gained certain other responses to TGF $\beta$ stimulation. In various cell types, TGF $\beta$ requires oncogenic RAS signaling to efficiently induce an EMT program $[4,5]$. Here we have shown that the TGF $\beta$ and EGFR pathways cooperate to activate an AP-1- and p63-dependent invasion program in various HER2+ and/or EGFR + breast cancer cell lines. Moreover, by enhancing the levels of EGFR, HB-EGF, JUN and, in particular, FOS family members, $\triangle \mathrm{Np} 63$ can promote the pro-oncogenic transcriptional program of SMAD and AP-1 in breast cancer cells. We thus identified an important mechanism by which oncogenic changes and environmental changes in breast tumors can re-direct TGF $\beta$-SMAD signaling towards tumor progression. This might help in the design of appropriate combination therapies, since clinical inhibitors of TGF $\beta$ might either inhibit or enhance tumor progression, depending on other oncogenic defects and genetic background. Cross-talk between EGFR and TGF $\beta$ signaling is 
Fig. 6 Ectopic overexpression of FOS counteracts the decrease in TGF $\beta$-induced gene activation after $\mathbf{p 6 3}$ depletion. $\mathbf{a}$, b The effect of ectopic FOS expression on TGF $\beta$ - and EGF-induced AP-1 and EGFR pathway components and target genes upon decrease by p63 knockdown. Control or Flag-FOS (F-FOS)-overexpressing MCF10A MII cells were transfected with non-targeting control (siNTC) or p63 siRNA, serum-starved with EGF for $16 \mathrm{~h}$, stimulated with $5 \mathrm{ng} / \mathrm{ml}$ TGF $\beta 1$ as indicated, or untreated, and analyzed by immnoblotting (a), and qRT-PCR analysis (b). Statistics were calculated using one-way analysis of variance (ANOVA). The data were further analyzed using Dunnett's multiple comparisons test and compared with the results from control cells transfected with non-targeting control (siNTC) and treated with TGF $\beta 1(5 \mathrm{ng} / \mathrm{ml})$. Results from three independent experiments are shown as mean $\pm \mathrm{SD} ; n s$, not significant, $* P<0.05$, $* * P<0.01$, and $* * * P<0.001$ (c) Schematic representation of the distinct (red, blue) and cooperative (green) contributions of TGF $\beta$, SMADs, EGF, JUN, FOS members and p63 to the combined EGF + TGF $\beta$ invasion program analyzed in this study. In the absence of EGF (left panel) or $\Delta \mathrm{Np} 63$ (middle panel) TGF $\beta$ (red pathway) mainly induces TGF $\beta$ target genes controlled by SMAD sites, such as MMP2, via activation of membrane-localized TGF $\beta$ RI (TBRI) and TGF $\beta$ RII (TBRII) which phosphorylate and activate SMAD2 and SMAD3 to bind to SMAD4. On the other arm $\triangle \mathrm{Np} 63$ and EGF (blue pathway) enable potent levels of EGF signaling via cell-membrane-localized EGFR, which triggers phosphorylation and activation of, amongst others, MAP kinases, which in the nucleus activate and induce JUN and FOS family members, that bind $\triangle \mathrm{Np} 63$ and subsequently can auto-regulate their own expression via AP-1 sites, and induce $E G F R$ and $H B-E G F$ (right panel). The combined action of TGF $\beta$ and EGF results in enhanced levels of AP-1 and enables and/or potentiates activation of SMAD/AP-1 target genes such as LAMB3, ITGA2 and WNT7 (green).

possible at multiple levels, e.g., by post-translational regulation of the SMAD proteins by AKT and ERK $[4,5,13,14]$ and by induction of TGF $\beta 1$ and HB-EGF [9]. Based on our experiments with specific chemical inhibitors the MEK-ERK pathway appeared to be most critical for the pro-invasive cooperation between EGF and TGF $\beta$ in MCF10A-MII cells, and for the activation of AP-1. However, SMAD3-Ser208 phosphorylation by AKT appears to be critical in other cell types [14]. Interestingly, in basal-like and mesenchymal breast cancers the PI3K-AKT and MEKERK pathways are often activated, resulting in high levels of JUN and FOSL1, whereas luminal A breast cancers do not show activation of the ERK1/2 MAP-kinase pathway [44-47]. Luminal and estrogen-responsive breast cancers express low levels of AP-1 [23, 48] and appear to respond to TGF $\beta$ only weakly; however, not all mesenchymal breast cancers express high levels of p63. Moreover, EGFR signaling appears to exert different roles in breast cancer cells during invasion of primary tumors, dissemination and metastasis [49].

In the HER2+/EGFR + breast cancer cell lines examined here, EGF by itself already induced high levels of AP-1 protein, but only low levels of invasion related gene expression and subsequent cell invasion. On the other hand, TGF $\beta / S M A D$ signaling by itself was not sufficient. In the model in Fig. 6c, we have schematically depicted the distinct and cooperative contributions of TGF $\beta$, SMADs, EGF, JUN, FOS and p63 to the invasion program. It should be noted that autocrine TGF $\beta$ signaling to some extent might contribute to the effects of EGF alone. We also would like to stress that some of the TGF $\beta$ effects on AP- 1 appear to be largely EGF-independent, e.g., TGF $\beta$ - induction of JUN and JUNB mRNA and protein in MII cells (Fig. 3a, b). However, we found that the synergism between EGF and TGF $\beta$ pathways is important for efficient recruitment of JUNB, FOSL1 and p63 to the promoter regions of genes involved in the late TGF $\beta$-induced invasion program such as $L A M B 3$ and ITGA2.

The mechanism by which p63 enhances SMAD- and AP1-dependent gene expression remains to be further elucidated. We found that $\triangle$ Np63 enhances EGFR-ERK signaling and AP-1 levels by activating the EGFR and HBEGF genes, directly binding to various $F O S$ family gene loci and activating their transcription, and interacting with both SMAD2/3 and JUNB proteins. p63 might thus stabilize the formation of a complex between SMAD and AP-1 or enhance complex formation on the chromatin. However, the role of the $\alpha, \beta, \gamma$, and $\varepsilon$ isoforms of $\Delta \mathrm{Np} 63$ is still unclear. In fact, expression of $\Delta \mathrm{Np} 63 \alpha$ has been found to be suppressed by oncogenic PI3K, AKT and RAS [50]. It should further be noted that the p63 family members p53 and p73 also have been found to functionally and physically interact with specific AP-1 components [20, 51, 52].

Finally, our results on TGF $\beta$-SMAD and p63-EGFR-AP1 cooperation may be relevant for the reported inhibitory effects of TGF $\beta$ on the cellular response to anti-cancer drugs. The mechanisms of EMT-associated, TGF $\beta$-induced drug-resistance, are not known, but EGFR, MEK-ERK and AP-1 are likely to be involved [29, 53-59].

In summary, we have identified specific oncogenic functions of the TGF $\beta$-SMAD, EGFR, and p63 pathways in EMT and invasion of HER2 + and/or EGFR + breast cancer cells. These functions are of importance for future personalized cancer therapeutic strategies, in particular for patients with tumors with $\Delta \mathrm{Np} 63$ expression.

\section{Materials and methods}

\section{Cell culture}

MCF10A MI and MII cells were obtained from Dr Fred Miller (Barbara Ann Karmanos Cancer Institute, Detroit, USA) and maintained at $37{ }^{\circ} \mathrm{C}$ and $5 \% \mathrm{CO}_{2}$ in DMEM/F12 (Gibco), supplemented with 5\% fetal bovine serum (FBS) (Biowest), $20 \mathrm{ng} / \mathrm{ml}$ EGF (PeproTech), $100 \mathrm{ng} / \mathrm{ml}$ cholera toxin (Sigma-Aldrich), $0.5 \mu \mathrm{g} / \mathrm{ml}$ hydrocortisone (SigmaAldrich), $10 \mu \mathrm{g} / \mathrm{ml}$ insulin (Sigma-Aldrich) (complete 
medium). Cells were starved in DMEM/F12 supplemented with $0.2 \% \mathrm{FBS}, 100 \mathrm{ng} / \mathrm{ml}$ cholera toxin, $0.5 \mu \mathrm{g} / \mathrm{ml}$ hydrocortisone, and $10 \mu \mathrm{g} / \mathrm{ml}$ insulin, with or without $20 \mathrm{ng} / \mathrm{ml}$ EGF for $16 \mathrm{~h}$ prior to TGF $\beta$ treatment. HCC 1954 breast cancer cells (obtained from Dr Andrew J. G. Simpson, Ludwig Cancer Research, New Your, USA), HCC1937 and HCC202 breast cancer cells (obtained from SE Le Dévédec, Leiden Academic Center for Drug Research, Leiden, the Netherlands) were maintained in RPMI-1640 (SigmaAldrich), supplemented with 10\% FBS (Biowest). Cells were kept in $0.2 \%$ FBS starvation media with or without EGF $(20 \mathrm{ng} / \mathrm{ml})$ for $16 \mathrm{~h}$ prior to TGF $\beta$ treatment. The cell lines were frequently tested for absence of mycoplasma and were authenticated by identity testing.

A detailed description of the materials and methods, including the primer sequences used for qRT-PCR (Table S1) and ChIP-qPCR (Table S2), used in this study is available in the online Supplementary Material and Methods.

Acknowledgements We thank our colleagues, in particular Maria Tsioumpekou, for valuable discussion. David Baker and David van IJzendoorn for the Flag-FOS lentiviral vector. The HCC-1954 cells were kindly provided by Otavia L. Caballero and Andrew J.G. Simpson, Ludwig Cancer Research, New York, USA, and the HCC1937 and HCC202 cells by SE Le Dévédec, Leiden Academic Center for Drug Research, Leiden, the Netherlands. This work was supported by the Swedish Cancer Foundation (2016/468 to PtD, 2018/ 439 to KM); Swedish Research Council (2015-02757 to C-HH); European Research Council (787472 to C-HH); and Cancer Genomics Centre Netherlands (CGC.NL to PtD).

Author contributions AS, EV and HvD conceived the study. AS, EV, $\mathrm{OV}$ and $\mathrm{YB}$ performed the experiments. HvD and AS wrote the article, with additional input from C-HH and PtD, MM, AM, KM, C-HH, PtD and HvD supervised the overall study.

\section{Compliance with ethical standards}

Conflict of interest The authors declare that they have no conflict of interest.

Publisher's note Springer Nature remains neutral with regard to jurisdictional claims in published maps and institutional affiliations.

Open Access This article is licensed under a Creative Commons Attribution 4.0 International License, which permits use, sharing, adaptation, distribution and reproduction in any medium or format, as long as you give appropriate credit to the original author(s) and the source, provide a link to the Creative Commons license, and indicate if changes were made. The images or other third party material in this article are included in the article's Creative Commons license, unless indicated otherwise in a credit line to the material. If material is not included in the article's Creative Commons license and your intended use is not permitted by statutory regulation or exceeds the permitted use, you will need to obtain permission directly from the copyright holder. To view a copy of this license, visit http://creativecommons. org/licenses/by/4.0/.

\section{References}

1. Roberts AB, Anzano MA, Lamb LC, Smith JM, Frolik CA, Marquardt $\mathrm{H}$. et al. Isolation from murine sarcoma cells of novel transforming growth factors potentiated by EGF. Nature.1982;295:417-9.

2. Moses HL, Roberts AB, Derynck R. The discovery and early days of TGF- $\beta$ : a historical perspective. Cold Spring Harb Perspect Biol. 2016;8:a021865.

3. Lemmon MA, Schlessinger J. Cell signaling by receptor tyrosine kinases. Cell. 2010;141:1117-34.

4. Massague J. TGF $\beta$ signalling in context. Nat Rev Mol Cell Biol. 2012;13:616-30.

5. Katsuno Y, Lamouille S, Derynck R. TGF- $\beta$ signaling and epithelial-mesenchymal transition in cancer progression. Curr Opin Oncol. 2013;25:76-84.

6. Akhurst RJ, Padgett RW. Matters of context guide future research in TGF $\beta$ superfamily signaling. Sci Signal. 2015;8:re10.

7. David CJ, Massague J. Contextual determinants of TGF $\beta$ action in development, immunity and cancer. Nat Rev Mol Cell Biol. 2018;19:419-35.

8. Wilson CA, Cajulis EE, Green JL, Olsen TM, Chung YA, Damore MA. et al. HER-2 overexpression differentially alters transforming growth factor- $\beta$ responses in luminal versus mesenchymal human breast cancer cells. Breast Cancer Res. 2005;7:R1058-79.

9. Chow A, Arteaga CL, Wang SE. When tumor suppressor TGF $\beta$ meets the HER2 (ERBB2) oncogene. J Mammary Gland Biol Neoplasia. 2011;16:81-8.

10. Hill CS. Transcriptional control by the SMADs. Cold Spring Harb Perspect Biol. 2016;8:pii: a022079.

11. Derynck R, Budi EH. Specificity, versatility, and control of TGF- $\beta$ family signaling. Sci Signal. 2019;12:pii: eaav5183.

12. Ikushima H, Miyazono K. TGF-beta signal transduction spreading to a wider field: a broad variety of mechanisms for contextdependent effects of TGF- $\beta$. Cell Tissue Res. 2012;347:37-49.

13. Sundqvist A, ten Dijke P, van Dam H. Key signaling nodes in mammary gland development and cancer: Smad signal integration in epithelial cell plasticity. Breast Cancer Res. 2012;14:204.

14. Huang F, Shi Q, Li Y, Xu L, Xu C, Chen F. et al. HER2/EGFRAKT signaling switches TGF $\beta$ from inhibiting cell proliferation to promoting cell migration in breast cancer. Cancer Res. 2018;78:6073-85.

15. Shaulian E, Karin M. AP-1 as a regulator of cell life and death. Nat Cell Biol. 2002;4:E131-6.

16. Eferl R, Wagner EF. AP-1: a double-edged sword in tumorigenesis. Nat Rev Cancer. 2003;3:859-68.

17. Hess J, Angel P, Schorpp-Kistner M. AP-1 subunits: quarrel and harmony among siblings. J Cell Sci. 2004;117:5965-73.

18. Durchdewald M, Angel P, Hess J. The transcription factor Fos: a Janus-type regulator in health and disease. Histol Histopathol. 2009;24:1451-61.

19. Lopez-Bergami P, Lau E, Ronai Z. Emerging roles of ATF2 and the dynamic AP1 network in cancer. Nat Rev Cancer. 2010;10:65-76.

20. Shaulian E. AP-1-The Jun proteins: oncogenes or tumor suppressors in disguise? Cell Signal. 2010;22:894-9.

21. Vierbuchen T, Ling E, Cowley CJ, Couch $\mathrm{CH}$, Wang X, Harmin DA. et al. AP-1 transcription factors and the BAF complex mediate signal-dependent enhancer selection. Mol Cell. 2017;68:1067-82. e12.

22. Madrigal P, Alasoo K. AP-1 takes centre stage in enhancer chromatin dynamics. Trends Cell Biol. 2018;28:509-11.

23. Belguise K, Kersual N, Galtier F, Chalbos D. FRA-1 expression level regulates proliferation and invasiveness of breast cancer cells. Oncogene. 2005;24:1434-44. 
24. Ozanne BW, Spence HJ, McGarry LC, Hennigan RF. Transcription factors control invasion: AP-1 the first among equals. Oncogene. 2007;26:1-10.

25. Sundqvist A, Zieba A, Vasilaki E, Herrera Hidalgo C, Soderberg O, Koinuma D. et al. Specific interactions between Smad proteins and AP-1 components determine TGF $\beta$-induced breast cancer cell invasion. Oncogene. 2012;32:3606-15.

26. Desmet CJ, Gallenne T, Prieur A, Reyal F, Visser NL, Wittner BS. et al. Identification of a pharmacologically tractable Fra-1/ ADORA2B axis promoting breast cancer metastasis. Proc Natl Acad Sci USA. 2013;110:5139-44.

27. Tam WL, Lu H, Buikhuisen J, Soh BS, Lim E, Reinhardt F. et al. Protein kinase $\mathrm{C}$ alpha is a central signaling node and therapeutic target for breast cancer stem cells. Cancer Cell. 2013;24:347-64.

28. Dhillon AS, Tulchinsky E. FRA-1 as a driver of tumour heterogeneity: a nexus between oncogenes and embryonic signalling pathways in cancer. Oncogene. 2015;34:4421-28.

29. Bakiri L, Macho-Maschler S, Custic I, Niemiec J, Guio-Carrion A, Hasenfuss SC. Fra-1/AP-1 induces EMT in mammary epithelial cells by modulating Zeb1/2 and TGF $\beta$ expression. Cell Death Differ. 2015;22:336-50.

30. Zhang Y, Feng XH, Derynck R. Smad 3 and Smad4 cooperate with c-Jun/c-Fos to mediate TGF- $\beta$-induced transcription. Nature. 1998;394:909-13.

31. Koinuma D, Tsutsumi S, Kamimura N, Taniguchi H, Miyazawa $\mathrm{K}$, Sunamura M. et al. Chromatin immunoprecipitation on microarray analysis of Smad2/3 binding sites reveals roles of ETS1 and TFAP2A in transforming growth factor $\beta$ signaling. Mol Cell Biol. 2009;29:172-86.

32. Sundqvist A, Morikawa M, Ren J, Vasilaki E, Kawasaki N, Kobayashi M. et al. JUNB governs a feed-forward network of TGF $\beta$ signaling that aggravates breast cancer invasion. Nucleic Acids Res. 2018;46:1180-95.

33. Chen Y, Peng Y, Fan S, Li Y, Xiao ZX, Li C. A double dealing tale of p63: an oncogene or a tumor suppressor. Cell Mol Life Sci. 2018;75:965-73.

34. Gatti V, Bongiorno-Borbone L, Fierro C, AnnicchiaricoPetruzzelli M, Melino G, Peschiaroli A. p63 at the crossroads between stemness and metastasis in breast cancer. Int J Mol Sci. 2019;20:pii: E2683.

35. Vasilaki E, Morikawa M, Koinuma D, Mizutani A, Hirano Y, Ehata $\mathrm{S}$. et al. Ras and TGF- $\beta$ signaling enhance cancer progression by promoting the DeltaNp63 transcriptional program. Sci Signal. 2016;9:ra84

36. Wiercinska E, Naber HP, Pardali E, van der Pluijm G, van Dam $\mathrm{H}$, ten Dijke P. The TGF- $\beta /$ Smad pathway induces breast cancer cell invasion through the up-regulation of matrix metalloproteinase 2 and 9 in a spheroid invasion model system. Breast Cancer Res Treat. 2011;128:657-66.

37. Soule HD, Maloney TM, Wolman SR, Peterson Jr. WD, Brenz R, McGrath CM. et al. Isolation and characterization of a spontaneously immortalized human breast epithelial cell line, MCF-10. Cancer Res. 1990;50:6075-86.

38. Dawson PJ, Wolman SR, Tait L, Heppner GH, Miller FR. MCF10AT: a model for the evolution of cancer from proliferative breast disease. Am J Pathol. 1996;148:313-9.

39. Carroll DK, Carroll JS, Leong CO, Cheng F, Brown M, Mills AA. et al. p63 regulates an adhesion programme and cell survival in epithelial cells. Nat Cell Biol. 2006;8:551-61.

40. Eferl R, Ricci R, Kenner L, Zenz R, David JP, Rath M. et al. Liver tumor development. c-Jun antagonizes the proapoptotic activity of p53. Cell. 2003;112:181-92.

41. Gatti V, Fierro C, Compagnone M, Giangrazi F, Markert EK, Bongiorno-Borbone L. et al. $\Delta \mathrm{Np} 63$ regulates the expression of hyaluronic acid-related genes in breast cancer cells. Oncogenesis. 2018;7:65

42. Buckley NE, Conlon SJ, Jirstrom K, Kay EW, Crawford NT, O'Grady A. et al. The $\triangle \mathrm{Np} 63$ proteins are key allies of BRCA1 in the prevention of basal-like breast cancer. Cancer Res. 2011;71:1933-44.

43. Leong CO, Vidnovic N, DeYoung MP, Sgroi D, Ellisen LW. The p63/p73 network mediates chemosensitivity to cisplatin in a biologically defined subset of primary breast cancers. J Clin Invest. 2007;117:1370-80.

44. Stephens PJ, Tarpey PS, Davies H, Van Loo P, Greenman C, Wedge DC. et al. The landscape of cancer genes and mutational processes in breast cancer. Nature. 2012;486:400-4.

45. Ellis MJ, Ding L, Shen D, Luo J, Suman VJ, Wallis JW. et al. Whole-genome analysis informs breast cancer response to aromatase inhibition. Nature. 2012;486:353-60.

46. Shah SP, Roth A, Goya R, Oloumi A, Ha G, Zhao Y. et al. The clonal and mutational evolution spectrum of primary triplenegative breast cancers. Nature. 2012;486:395-9.

47. Cancer Genome Atlas Network. Comprehensive molecular portraits of human breast tumours. Nature. 2012;490:61-70.

48. Baan B, Pardali E, ten Dijke P, van Dam H. In situ proximity ligation detection of c-Jun/AP-1 dimers reveals increased levels of c-Jun/Fra1 complexes in aggressive breast cancer cell lines in vitro and in vivo. Mol Cell Proteom. 2010;9:1982-90.

49. Ali R, Wendt MK. The paradoxical functions of EGFR during breast cancer progression. Signal Transduct Target Ther. 2017;2:16042.

50. Hu L, Liang S, Chen H, Lv T, Wu J, Chen D. et al. Snp63 $\alpha$ is a common inhibitory target in oncogenic PI3K/Ras/Her2-induced cell motility and tumor metastasis. Proc Natl Acad Sci USA. 2017;114:E3964-73.

51. Wagner EF, Nebreda AR. Signal integration by JNK and p38 MAPK pathways in cancer development. Nat Rev Cancer. 2009;9:537-49.

52. Subramanian D, Bunjobpol W, Sabapathy K. Interplay between TAp73 protein and selected activator protein-1 (AP-1) family members promotes AP-1 target gene activation and cellular growth. J Biol Chem. 2015;290:18636-49.

53. Kurrey NK, Jalgaonkar SP, Joglekar AV, Ghanate AD, Chaskar PD, Doiphode RY. et al. Snail and slug mediate radioresistance and chemoresistance by antagonizing p53-mediated apoptosis and acquiring a stem-like phenotype in ovarian cancer cells. Stem Cells. 2009;27:2059-68.

54. Bhola NE, Balko JM, Dugger TC, Kuba MG, Sanchez V, Sanders M. et al. TGF- $\beta$ inhibition enhances chemotherapy action against triple-negative breast cancer. J Clin Invest. 2013;123:1348-58.

55. Huang S, Holzel M, Knijnenburg T, Schlicker A, Roepman P, McDermott U. et al. MED12 controls the response to multiple cancer drugs through regulation of TGF- $\beta$ receptor signaling. Cell. 2012;151:937-50.

56. Lu D, Chen S, Tan X, Li N, Liu C, Li Z. et al. Fra-1 promotes breast cancer chemosensitivity by driving cancer stem cells from dormancy. Cancer Res. 2012;72:3451-6.

57. Xue Z, Vis DJ, Bruna A, Sustic T, van Wageningen S, Batra AS. et al. MAP3K1 and MAP2K4 mutations are associated with sensitivity to MEK inhibitors in multiple cancer models. Cell Res. 2018;28:719-29.

58. van Staalduinen J, Baker $\mathrm{D}$, ten Dijke $\mathrm{P}$, van Dam $\mathrm{H}$. Epithelial-mesenchymal-transition-inducing transcription factors: new targets for tackling chemoresistance in cancer? Oncogene. 2018;37:6195-211.

59. van IJzendoorn DGP, Forghany Z, Liebelt F, Vertegaal AC, Jochemsen AG, Bovée JVMG. et al. Functional analyses of a human vascular tumor FOS variant identify a novel degradation mechanism and a link to tumorigenesis. J Biol Chem. 2017;292:21282-90. 